\title{
MICROBIOLOGICAL ANALYSIS OF DRINKING WATER OF KATHMANDU VALLEY
}

\author{
Tista Prasai*, Binod Lekhak**, Dev Raj Joshi** and Madhav Prasad Baral*** \\ *Nepal Academy of Science and Technology, Kathmandu, Nepal. \\ **Central Department of Microbiology, Tribhuvan University, Kathmandu, Nepal. \\ ***National School of Sciences, Kathmandu, Nepal.
}

\begin{abstract}
Drinking water quality assessment in Kathmandu valley has always been crucial with reference to public health importance. A study was conducted to evaluate the quality of drinking water of the valley. A total of 132 drinking water samples were randomly collected from 49 tube wells, 57 wells, 17 taps and 9 stone spouts in different places of Kathmandu valley. The samples were analyzed for microbiological parameters. Total plate and coliform count revealed that $82.6 \%$ and $92.4 \%$ of drinking water samples found to cross the WHO guideline value for drinking water. During the study, 238 isolates of enteric bacteria were identified, of which $26.4 \%$ were Escherichia coli, $25.6 \%$ were Enterobacter spp, 23\% were Citrobacter spp, 6.3\% were Pseudomonas aeruginosa, 5.4\% were Klebsiella spp, 4.0\% were Shigella spp, 3.0\% were Salmonella typhi, 3.0\% were Proteus vulgaris, 3.0\% were Serratia spp and $1.0 \%$ were Vibrio cholerae.
\end{abstract}

Key words: Drinking water; Public health; Coliform; Bacteria.

\section{INTRODUCTION}

Drinking water is indispensable for human existence. The Kathmandu valley suffers a severe drinking water supply crisis, particularly in the dry seasons of every year. The drinking water supplies in the cities of the valley is intermittent. Nearly all of the surface sources and ground water sources have been exploited. The growing imbalance between supply and demand has led to chronic shortages and competition that have resulted in pollution and environmental degradation. Apart from quantitative shortages, the quality of drinking water in the Kathmandu valley is becoming a serious public health issue for the past few years. The quality of water for drinking has deteriorated because of the inadequacy of treatment plants, direct discharge of untreated sewage into rivers and inefficient management of the piped water distribution system (UNEP, 2001).

Diseases caused by contaminated water are among the ten most prevalent water borne diseases in Nepal (DoHS, 1998). Diarrhoea, which is caused by poor sanitation, hygiene and water quality, is one of the most prevalent water borne disease in Nepal. During 1995/96, the incidence of diarrhoea among children below five years of age was 131 per 1,000 children. The mortality rate due to the diarrhoea was 0.34 per 1000 children under five years of age, while the case of fatality rate was 2.56 per 1,000 (CBS, 2001).

In Nepal, the incidence of diarrhoea is increasing in alarming rate. A report obtained from Teku Hospital in Kathmandu shows that $16.5 \%$ of all deaths were due to water-borne disease (Metcalf, 2000). Probably the most important pathogenic bacteria transmitted by the water route are
Salmonella typhi, the organism causing typhoid fever, and Vibrio cholerae, the organism causing cholera (Madigan et al., 1997).

Ideally, drinking water should not contain any microorganisms known to be pathogenic or any bacteria indicative of faecal pollution. Detection of faecal indicator bacteria in drinking water provides a very sensitive method of quality assessment and it is not possible to examine water for every possible pathogen that might be present (WHO, 1993).

\section{MATERIALS AND METHODS}

Drinking water samples from different sources in Kathmandu valley were collected and transported by standard methods as mentioned in APHA, 1998. Random sampling was adopted for the study. Microbiological analysis of water samples was conducted in Environmental Laboratory of Nepal Academy of Science and Technology.

\section{Microbial Examination of Water Sample}

The total plate count was conducted by pour plate technique on plate count agar (PCA) and counting the colonies developed after the incubation at $37^{\circ} \mathrm{C}$ for 24 hours (APHA, 1998). The total coliforms were enumerated by the membrane filtration (MF) technique as described by APHA, 1998. Detection of Salmonella and Shigella species were done by the enrichment of water samples on Selenite F broth, followed by isolation of the typical organism on selective medium, Xylose Lysine Deoxycholate Agar (XLD). (Collee et al., 1996)

Detection of Vibrio cholerae was done by enriching the samples in $1 \%$ alkaline peptone water for 6 to 8 hours followed

Author for Correspondence: Tista Prasai, Nepal Academy of Science and Technology, GPO Box 3323, Kathmandu, Nepal. 
by isolation on Thiosulphate Citrate Bile salt sucrose (TCBS) agar medium (Collee et al., 1996).

All colonies with different characteristics on M-Endo agar, Xylose Lysine Deoxycholate Agar (XLD) agar and Thiosulphate Citrate Bile salt sucrose Agar (TCBS) were sub cultured onto Nutrient agar (NA) for purification. Enteric bacteria isolated on respective selective or differential media were identified on the basis of their colonial, morphological and Biochemical properties following Bergey's Manual of Determinative Bacteriology, 1994.

\section{RESULTS}

A total of 132 drinking water drinking water samples were collected from different places of Kathmandu valley, of which 35 were from tube wells, 21 from wells, 15 from tap waters and 8 from stone spouts of Kathmandu, Lalitpur and Bhaktapur districts. In totality samples from Kathmandu, Lalitpur and Bhaktapur contributed $59.8 \%, 32.6 \%$ and $7.6 \%$ respectively.

Ground water contributed $80.3 \%$, while $19.7 \%$ were collected from municipal drinking water sources and stone spouts.

\section{Bacteriological Analysis of Water}

\section{A. Total Plate Count}

Total plate count for total bacterial count performed for all water samples showed only $17.4 \%$ samples were within the WHO guideline value ( $<10 \mathrm{cfu} / \mathrm{ml}$ ). In source wise distribution of samples, $71.1 \%$ of tube well, $89.5 \%$ of well, $82.4 \%$ of tap and $100 \%$ of stone spout samples were exceeded the guideline value.

Table 1: Source wise Quality of Total bacterial Count of Water Samples.

\begin{tabular}{|c|c|c|c|c|}
\hline \multirow{2}{*}{$\begin{array}{l}\mathrm{S} \\
\mathrm{N}\end{array}$} & \multirow{2}{*}{ Source } & \multicolumn{2}{|c|}{$\begin{array}{c}\text { Percentage (\%) of Samples } \\
\text { compared with WHO guideline } \\
\text { Value }\end{array}$} & \multirow{2}{*}{$\begin{array}{l}\text { Total } \\
\text { number } \\
\text { of } \\
\text { Samples }\end{array}$} \\
\hline & & $\begin{array}{c}\text { Guideline } \\
\text { value }(<10 \\
\text { cfu/ml) }\end{array}$ & $\begin{array}{c}\text { Excess to } \\
\text { Guideline value } \\
\text { (>10 cfu/ml) }\end{array}$ & \\
\hline 1 & Tube well & $28.9 \%$ & $71.1 \%$ & 49 \\
\hline 2 & Well & $10.5 \%$ & $89.5 \%$ & 57 \\
\hline 3 & Tap water & $17.6 \%$ & $82.4 \%$ & 17 \\
\hline 4 & Stone Spout & $0 \%$ & $100 \%$ & 9 \\
\hline & Total & $17.4 \%$ & $82.6 \%$ & 132 \\
\hline
\end{tabular}

\section{B. Coliform count}

Source wise distribution of coliform count showed that the $85.7 \%$ of tube wells, $94.7 \%$ of wells, $100 \%$ of taps and $100 \%$ of stone spouts crossed WHO guideline value $(0 \mathrm{cfu} / 100 \mathrm{ml})$. (Fig. 1).

\section{Isolation and Identification of Bacteria}

In this study, 238 isolates of enteric bacteria obtained were identified as Escherichia coli (26.4\%), Enterobacter spp (25.6\%), Citrobacter spp (22.6\%), Pseudomonas aeruginosa (6.3\%), Klebsiella spp (5.4\%), Shigella spp (3.78\%), Salmonella typhi (3.3\%), Proteus vulgaris (2.9\%), Serratia spp (2.52\%), and Vibrio cholerae (0.84\%). (Fig. 2) The results revealed that $31.5 \%, 43.7 \%, 16.0 \%$ and $8.8 \%$ of isolates were
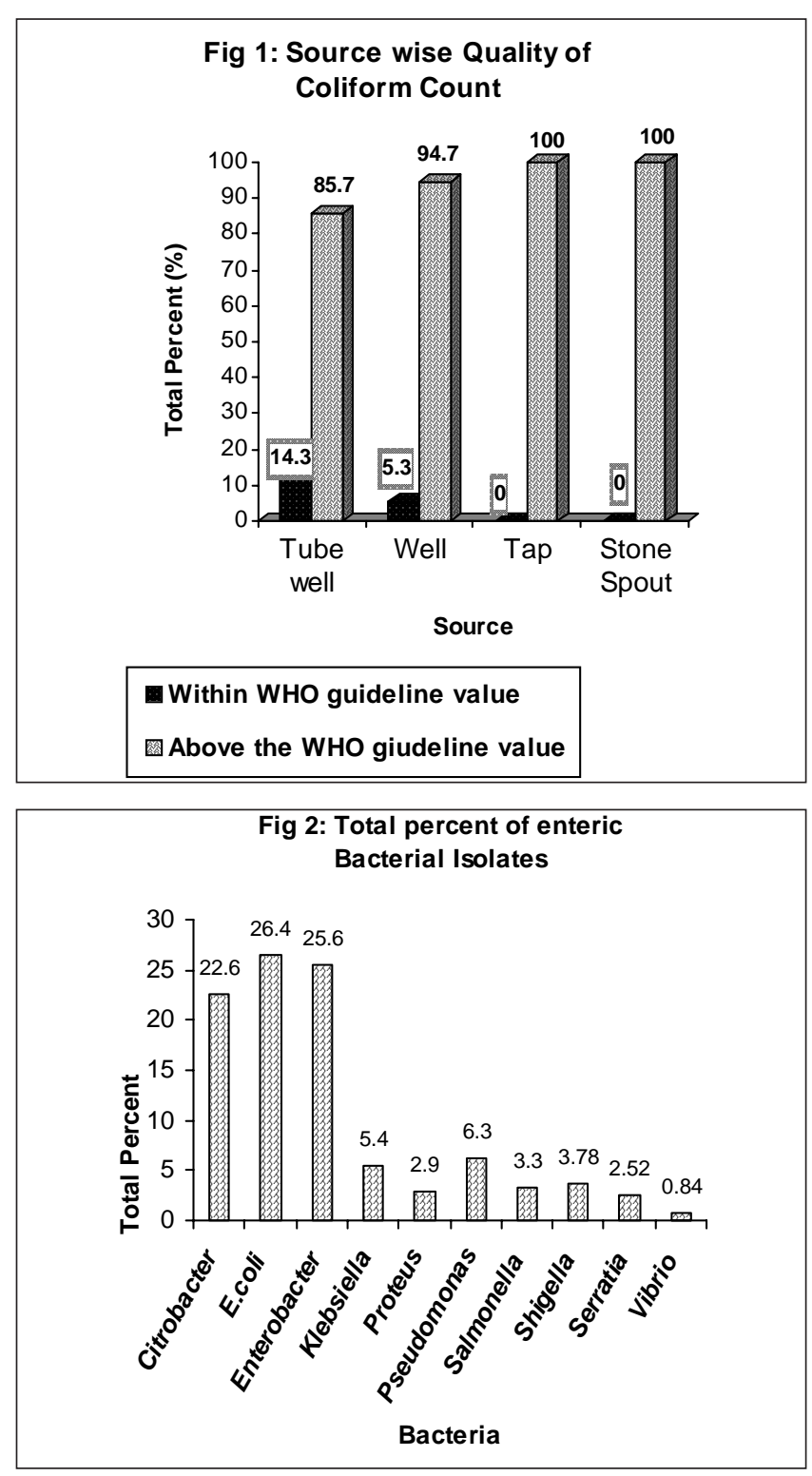

obtained from water samples of tube well, well, tap and stone spout sources.

\section{DISCUSSION}

The main objective of this study was evaluation of quality of water from different sources (tap, stone spout, tube well and well) from Kathmandu valley.

Heterotrophic plate counts and Coliform counts have been used extensively as a basis for regulating the microbial quality of drinking-water. In this study, both regulatory parameters were excessively above the WHO guideline values. Study results clearly indicated that most of the natural water sources are highly contaminated. The detection of pathogenic enteric bacteria in different sources of drinking water in Kathmandu valley also reveals the alarming situation for water borne epidemics in the valley.

Water quality indicates that pollution of the water is increasing alarmingly and that it has created serious threat to human health and environment. Bacteriological pollution of 
drinking water supplies may be either due to the failure of the disinfections of the raw water at the treatment plant or to the infiltration of contaminated water (sewage) through crossconnection, leakage points and back siphonage. In piped supplies, discontinuity increase the likelihood of contamination as the risk of back siphonage into the distribution network is increased when pipes are at lower pressure than the surroundings soil, which often contains leaked out effluent from leaking sewers.

The result clearly showed that the quality of the water consumed is critical in controlling infectious diseases and other health problems.

According to the WHO, the lack of safe water supply and of adequate means of sanitation is blamed for as much as $80 \%$ of all diseases in developing countries. In Nepal, morbidity and mortality rates from water borne disease are considered high particularly among children below the age of five.

A regular monitoring the water quality for improvement not only prevents disease and hazards but also checks the water resources from going further polluted (Trivedy and Goel, 1986). The conservation of water sources is very important to provide safe water. As far as possible, water sources must be protected from contamination by human and animal waste, which can contain a variety of bacterial, viral, protozoan and helminthes parasites. The control of drinking water quality in distribution networks remains a major challenge in urban areas. The protection of sources, treatment and distribution management are all-critical strategies in maintaining and improving piped water supplies.

\section{ACKNOWLEDGEMENT}

We are grateful to Nepal Academy of Science and Technology (NAST) for laboratory facilities.

\section{REFERENCES}

APHA. 1989. Standards Methods for the Examination of Water and Wastewater. $17^{\text {th }}$ edition, American Public Health Association, Washington, D.C.

APHA. 1998. Standards Methods for the Examination of Water and Wastewater. 20 $0^{\text {th }}$ edition, American Public Health Association, Washington, D.C.

CBS. 2001. Statistical Year Book of Nepal HMG, Central Bureau of Statistics.

Cheesbrough, M. 1993. Medical Laboratory Manual for Tropical countries. ELBS Reprinted Edition.

Collee, J.G., Frasher, A.G., Marmion, B.P., and Simmons, A. 1996. Mackie and McCartney Practical Medical Microbiology. Fourteenth Edition, Churchill Living Stone.

DoHS. 1998. Annual Report (1997/98). Kathmandu: DoHS, MoHP, GoN.

Holt, G.J., Krieg, R.N., Sneath, A.H.P., Staley, T.J. and Williams, T.S. 1994. Bergey's Manual of Determinative Bacteriology. Ninth Edition, International edition.

Madigan, Martinko, Parker. 1997. Brock Biology of Microorganisms. International Edition, Eighth Edition.

Metcalf and Eddy. 2000. Paper Presented at a Seminar on Ground water and Waste Water. Organized by Melamchi Water Supply Development Board, 14 February 2000, Kathmandu, Nepal.

Trivedi, R.K. and Goel, P.K. 1986. Chemical and Biological Methods for Water Pollution Studies. Environmental publication, Karad 415110. India.

UNEP. 2001. State of the Environment Nepal. United Nations Environment Programs (UNEP), in collaboration with MoPE/ HMGN; SACEP, ICIMOD and NORAD.

WHO. 1993. Guidelines for Drinking Water Quality, Volume I, II and III, World Health Organizations, Geneva.

WHO. 1996. Guidelines for Drinking Water Quality $2^{\text {nd }}$ edition. Volume II, Health criteria and other supporting information. World Health Organizations, Geneva. 